\title{
The role of cardiac MR in identifying annulus paradoxus, a specific marker for constrictive pericarditis
}

\author{
Kashif Kalam ${ }^{*}$, Werner Harmse ${ }^{2}$, Naeem Merchant ${ }^{2}$, Winnie Fu ${ }^{2}$ \\ From 18th Annual SCMR Scientific Sessions \\ Nice, France. 4-7 February 2015
}

\section{Background}

Distinguishing constrictive pericarditis from restrictive cardiomyopathy can be challanging. In normal subjects and many cardiac pathologies, the lateral mitral annulus compared to medial demonstrates more longitudinal excursion. This is due to the presence of more longitudinal fibres and lubrication offered by pericardium. Annulus paradoxus is a term used to define reversal of this phenomenon due to tethering of the pericardium and has been extensively reported as a specific marker of constrictive pericarditis in echocardiography by using tissue doppler imaging (TDI). TDI is a pulse wave doppler technique and has limitations due to aliasing and angle of interrrogation. We define an alternative way of demonstrating this phenomenon on CMR that will provide additive diagnostic power due to better spatial resolution.

\section{Methods}

64 retrospective patients were included in the study. 23 of these had CMR and surgical diagnosis of constrictive pericarditis. Of the remaining 41 patients, 19 were diagnosed as normal and 22 had alternative diagnoses of non-ischaemic cardiomyopathies (Restrictive cardiomypathy, hypertrophic cardiomyopathy, ARCV, non.compaction, Fabry's disease and dilated cardiomyopathy). We identified annular excursion by longitudinal motion of the medial and lateral mitral annulus in a 4 chamber SSFP view perpendicular to the transverse plane. Annular excursion was measured in end diastole and end systole. Annular excursion differences were calculated by subtracting the lateral annular excursion from that of the medial during the diastole and systole. A negative value indicated

${ }^{1}$ The Stephenson cardiovascular MR centre, Libin cardiovascular institute, Calgary, AB, Canada

Full list of author information is available at the end of the article paradoxical motion. We excluded studies with known wall motion abnormalities, severe valvular heart diease, prosthetic heart valves and poor image resolution due artifacts.

\section{Results}

$18(78 \%)$ of the patients with constrictive disease had paradoxical excursion of the mitral valve annulus. Mean annular excursion difference was -0.88 (-5.6 to 3.57).

Of those without constrictive disease $37(90 \%)$ did not show annulus paradoxus. This included $84 \%$ of the normal patients and $95 \%$ of those with other diagnoses. In this non-constrictive group the mean annular excursion difference was $2.31(-1.9$ to 6.37$)(\mathrm{p}<0.05$ compared to constrictive group). Normal group: $2.41(-1.93$ to 5.61). Other diagnosis group: 2.45 (-0.82 to 6.37).

Using negative annular excursion differences on MRI (annulus paradoxus) for constrictive cardiac disease our

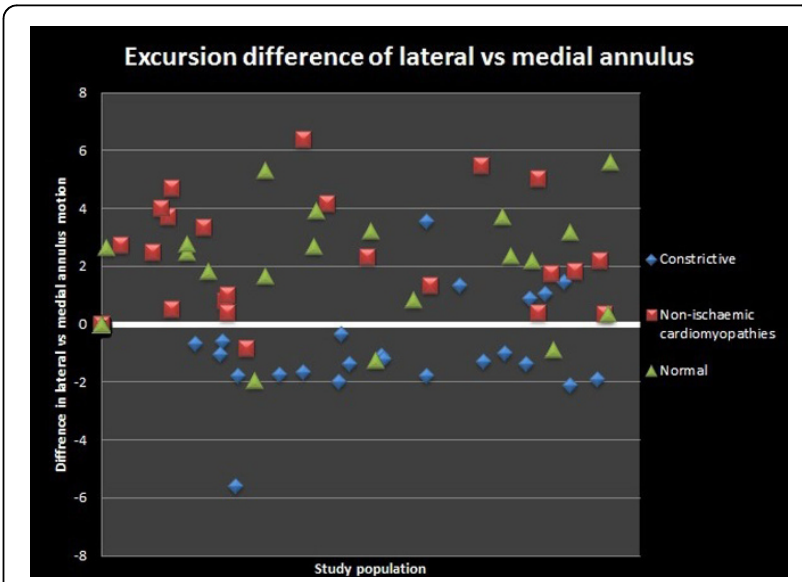

Figure 1 Scatter plot of excursion differences in the three groups 
Table 1 Mean annular motion and differences.

\begin{tabular}{|c|c|c|c|c|}
\hline & Number & $\begin{array}{l}\text { Mean medial annular Motion } \\
\qquad(\mathrm{mm})\end{array}$ & $\begin{array}{l}\text { Mean lateral annular Motion } \\
\qquad(\mathrm{mm})\end{array}$ & $\begin{array}{c}\text { Mean difference (negative indicating } \\
\text { Paradoxical motion) }\end{array}$ \\
\hline Study Population & 64 & 8.80 & 9.96 & 1.16 \\
\hline Pericardial constriction & 23 & 9.05 & 8.16 & -0.88 \\
\hline Non Pericardial constriction & 41 & 8.66 & 10.97 & 2.31 \\
\hline $\begin{array}{l}\text { Non ischemic } \\
\text { cardiomyopathies }\end{array}$ & 22 & 6.31 & 8.77 & 2.46 \\
\hline Normal & 19 & 11.37 & 13.52 & 2.14 \\
\hline \multicolumn{5}{|l|}{$\begin{array}{l}\text { P-values: Pericardial } \\
\text { constriction vs. }\end{array}$} \\
\hline Non Pericardial constriction & & 0.63 & $<0.0014$ & $<0.0005$ \\
\hline $\begin{array}{l}\text { Non-ischaemic } \\
\text { cardiomyopathies }\end{array}$ & & 0.0028 & 0.50 & $<0.0005$ \\
\hline Normal & & 0.003 & $<0.0005$ & $<0.0005$ \\
\hline
\end{tabular}

results showed a sensitivity of $78 \%$, specificity of $90 \%$, positive predictive value of $82 \%$ and negative predictive value of $88 \%$.

\section{Conclusions}

This study shows that annulus paradoxus is a specific and highly reproducible marker of constrictive pericarditis that can be accuratly estimated from 4 chamber SSFP cine CMR images. Unlike echocardiography, we are not dependent on body habitus and opertor skill to obtain high quality images and perform doppler interrogation.

\section{Funding}

None.

\section{Authors' details}

${ }^{1} T$ The Stephenson cardiovascular MR centre, Libin cardiovascular institute, Calgary, $A B$, Canada. ${ }^{2}$ Diagnostic imaging, University of Calgary, Calgary, AB, Canada.

Published: 3 February 2015
Submit your next manuscript to BioMed Central and take full advantage of:

- Convenient online submission

- Thorough peer review

- No space constraints or color figure charges

- Immediate publication on acceptance

- Inclusion in PubMed, CAS, Scopus and Google Scholar

- Research which is freely available for redistribution 